\title{
POTENSI SENYAWA BIOAKTIF TANAMAN KELOR PENGHAMBAT INTERAKSI ANGIOTENSIN-CONVERTING ENZYME 2PADA SINDROMA SARS-COV-2
}

\author{
The Potential of Moringa oleifera Bioactive Compounds for Inhibiting \\ Angiotensin-Converting Enzyme 2 Interaction in SARS-Cov-2 Syndrome
}

\author{
Maharani Pertiwi Koentjoro ${ }^{1 *}$, Adyan Donastin², Endry Nugroho Prasetyo ${ }^{3}$ \\ ${ }^{1}$ D4 Analis Kesehatan, Fakultas Kesehatan, Universitas Nahdlatul Ulama Surabaya, Jl. Jemursari No. 57, Surabaya \\ 2Program Studi Pendidikan Dokter, Fakultas Kedokteran, Universitas Nahdlatul Ulama Surabaya, Jl. Jemursari No. 57, Surabaya \\ ${ }^{3}$ Departemen Biologi, Fakultas Sains dan Analitika Data, Institut Teknologi Sepuluh Nopember, Gedung H, \\ Kampus ITS Sukolilo, Surabaya \\ *Email: maharani@unusa.ac.id
}

\begin{abstract}
Severe acute respiratory syndrome coronavirus-2 (SARS-CoV-2) disease (COVID-19) is a threat to human health. This infection is determined by the interaction of the spike S1 domain protein with angiotensin-converting enzyme 2 (ACE2) in the epithelial cells of the respiratory tract, especially the lungs. ACE2 inhibition is an important target in controlling COVID-19. Therefore, this study aims to explore the ability of apiin, epicatechin, and hesperetin from Moringa oleifera in interacting with the ACE2 using MOE 2008.10. The ligand molecules were prepared from PubChem database. The ACE2 protein was retrieved from Protein Data Bank (ID 1R4L) and analyzed for the active sites. Analysis of docking scores and hydrogen bonds of ACE2-ligand complex and active site showed that the affinity of flavonoids can be ranked as hesperetin > epicatechin > apiin $>\mathrm{C}_{19} \mathrm{H}_{23} \mathrm{Cl}_{2} \mathrm{~N}_{3} \mathrm{O}_{4}$. The results provided computational information that apiin, epicatechin, and hesperetin have the potential to prevent COVID-19 infection. The prediction of activity spectra for substances (PASS) score showed the ligand displays antiviral activity.
\end{abstract}

Keywords: apiin, COVID-19, epicatechin, hesperetin, SARS-CoV-2

\begin{abstract}
ABSTRAK
Infeksi severe acute respiratory syndrome coronavirus-2 (SARS-CoV-2) pada pandemi coronavirus disease 2019 (COVID-19) menjadi ancaman dunia kesehatan saat ini. Infeksi SARSCoV-2 ditentukan oleh interaksi protein spike envelope S1 domain dengan reseptor angiotensinconverting enzyme 2 (ACE2) yang diekspresikan pada sel epitel saluran pernafasan terutama paru-paru. Mekanisme penghambatan ACE2 menjadi target penting dalam pengendalian COVID19. Penelitian ini bertujuan mengeksplorasi kemampuan senyawa apiin, epicatechin, dan hesperetin dari Moringa oleifera dalam berinteraksi dengan sisi aktif ACE2 menggunakan metode penambatan molekul. Studi dilakukan dengan preparasi struktur molekul ligan dari PubChem database dan diolah dengan MOE 2008.10. Selanjutnya, data protein ACE2 (Protein Data Bank ID 1R4L) dianalisis sisi aktifnya untuk mengetahui lokasi penambatan ligan senyawa. Analisis skor docking dan ikatan hydrogen komplek ligan dan sisi aktif ACE2 menunjukkan bahwa afinitas flavonoid dapat diperingkatkan sebagai afinitas hesperetin $>$ epicatechin $>$ apiin $>\mathrm{C}_{19} \mathrm{H}_{23} \mathrm{Cl}_{2} \mathrm{~N}_{3} \mathrm{O}_{4}$. Ketiga ligan senyawa yang terkandung dalam $M$. oleifera secara in silico mampu mengikat sisi aktif ACE2, sehingga berpotensi mencegah infeksi COVID-19. Skor PASS (prediction of activity spectra for substances) menunjukkan aktivitas biologis ligan yang menyerupai antiviral.
\end{abstract}

Kata Kunci: apiin, COVID-19, epicatechin, hesperetin, SARS-CoV-2 


\section{PENDAHULUAN}

Akhir tahun 2019, coronavirus jenis baru yaitu severe acute respiratory syndrome coronavirus-2 (SARS-CoV-2) telah menimbulkan kejadian luar biasa (KLB) coronavirus disease 2019 (COVID-19) di seluruh penjuru dunia, tidak terkecuali di Indonesia (Kementerian Kesehatan 2020). SARS-CoV-2 termasuk dalam genus Betacoronavirus dan famili Coronaviridae. Beberapa anggota dari Coronaviridae merupakan penyebab infeksi saluran pernafasan atas dan menimbulkan gejala minor, yaitu human coronavirus (HCoV) tipe HcoV-229E, HcoV-NL63, HcoV-OC43 dan HKU1. Sedangkan severe acute respiratory syndrome coronavirus (SARS-CoV), Middle East respiratory syndrome coronavirus (MERS-CoV) dan SARS-CoV-2 memiliki kemampuan bereplikasi pada saluran pernafasan bawah dan menyebabkan pneumonia (Bahadur et al. 2020).

COVID-19 memiliki tingkat transmisi atau penyebaran tinggi, dengan tingkat kematian yang rendah (Xu et al. 2020). Virus ini utamanya bertranmisi melalui rute saluran pernafasan dalam bentuk droplet dan kemungkinan lain dalam rute fekal-oral (faecal-oral) (Heller et al. 2020). Virus ini diketahui mampu bertahan berada pada aerosol dan pada berbagai permukaan benda. Data dari Organisasi Kesehatan Dunia (World Health Organization, WHO) pada awal tahun 2020 menunjukkan bahwa $80 \%$ pasien yang terinfeksi COVID-19 tidak menunjukkan gejala. Su et al. (2020a) melaporkan perbedaan karakteristik klinis dalam satu keluarga yang terinfeksi SARSCoV-2, antara lain demam, batuk, sesak/nyeri dada, kelelahan dan sakit tenggorokan dan di antaranya tidak menunjukkan gejala.

Partikel SARS-CoV-2 tediri dari untai tunggal positif asam ribonukleat (+SsRNA) yang dikelilingi oleh protein membran (M) dan protein envelope (E). SARS-CoV-2 juga memiliki protein spike envelope (S) yang mampu berinteraksi dengan reseptor angiotensin-converting enzyme 2 (ACE2) pada sel inang (Mourad dan Levy 2020). Protein spike ini terdiri dari subunit 1 (S1) dan subunit 2 (S2), dimana protein spike S1 akan berinteraksi dengan protein membran ACE2 sel inang. Interaksi ini akan mengubah konformasi membran sel inang dan membawa partikel SARS-CoV-2 masuk ke dalam sitoplasma (Saha et al. 2020). Virus memasuki sel inang melalui fusi membran dan endositosis (Xia et al. 2020).

ACE2 merupakan glikoprotein integral membran tipe 1 yang diekspresikan dan diaktifkan hampir pada semua jaringan tubuh manusia (Homo sapiens). Ekspresi tertinggi dari ACE2 diamati pada saluran pernafasan (paru-paru), saluran pencernaan dan jantung. ACE2 memiliki kemiripan urutan basa nukeotida sebesar $42 \%$ dengan angiotensinconverting enzyme (ACE) (Wiese et al. 2020). Hal ini menyebabkan ACE dan ACE2 memiliki karakter protein yang homolog, tetapi keduanya memiliki perbedaan spesifisitas substrat (Sharifi et al. 2013). Kemiripan urutan basa nukleotida pada sisi katalitik ACE dan ACE2 adalah sebesar $61 \%$. ACE2 berfungsi sebagai karboksipeptidase, membelah residu hidrofobik/basa tunggal dari terminal-C substratnya. ACE2 secara efisien menghidrolisis vasokonstriktor poten angiotensin II menjadi angiotensin (1-7). ACE2 tidak banyak ditemukan dalam sirkulasi darah, tetapi enzim ini banyak diekspresikan pada membran sel epitel paru-paru dan pencernaan, dimana wilayah tersebut merupakan jalur utama masuknya virus ke dalam tubuh manusia (Jia 2016). Keberadaan ACE2 yang berlebihan menjadi peluang masuknya SARSCoV-2 dan menjadi awal dari patogenesisnya. Mekanisme penghambatan kerja ACE2 atau penekanan ekspresi enzim ini menjadi salah satu target dalam pengendaliannya (Mourad dan Levy 2020, Zheng et al. 2020).

Beberapa obat yang berpotensi digunakan untuk menghambat proses interaksi protein spike S1 di antaranya adalah umifenovir (Arbidol) (Blaising et al. 2013), baricitinib (Cantini et al. 2020), chloroquine (Schrezenmeier dan Dorner 2020), camostat, nafamostat, gabexate, dan APNO1 (Rekombinan Human ACE2) (Lisi et al. 2020). Chloroquine dan hydroxychloroquine merupakan obat yang paling sering digunakan untuk pengobatan pasien COVID-19. Mekanisme kerja dari obat ini adalah mengubah glikosilasi terminal dari ACE2 yang menyebabkan gangguan aktivitas interaksi partikel virus dengan sel inang (Sun et al. 2020). Tetapi, uji klinis menyebutkan bahwa pengobatan chloroquine dan hydroxychloroquine memiliki efek samping dan memerlukan manajemen yang tepat dalam pemakaiannya (Bahadur et al. 2020). 
Moringa oleifera atau yang lebih dikenal sebagai kelor merupakan tanaman tropis yang dibudidayakan dan menjadi salah satu sumber nutrisi masyarakat Indonesia (Riastiwi et al. 2018). Pada penelitian sebelumnya, M. oleifera memiliki aktivitas antioksidan anti-aging (Imamsari et al. 2018). Kandungan tanaman tersebut diketahui terutama flavonoid mampu mendenaturasi dan mengganggu fungsi banyak makromolekul termasuk ACE (Khan et al. 2019). Oleh karena itu, tujuan penelitian ini adalah untuk memprediksi apakah senyawa bioaktif flavonoid dari $M$. oleifera antara lain apiin, epicatechin, dan hesperetin mampu berinteraksi dengan reseptor ACE2, sehingga berpeluang sebagai inhibitor interaksi SARSCoV-2 dan sel inang. Metode yang digunakan adalah melalui molecular docking. Hasil studi ini diharapkan mampu memberikan pemodelan molekuler dan pendekatan berbasis informatika dalam menjelaskan senyawa-senyawa bioaktif dari $M$. oleifera yang berpotensi sebagai kandidat pencegahan infeksi SARS-CoV-2 secara alami.

\section{BAHAN DAN METODE}

\section{Tempat dan waktu penelitian}

Penelitian ini dilakukan di Laboratorium Biologi Molekuler, Fakultas Kesehatan, Universitas Nahdlatul Ulama Surabaya pada bulan April sampai dengan Mei 2020.

\section{Bahan}

Hardware yang digunakan adalah Laptop Intel ${ }^{\circledR}$ Core ${ }^{\mathrm{TM}}$ i5-3340 M CPU @2.700GhZ, 2.70 Ghz dengan sistem operasi Microsoft Windows 10 pro dan 64 bits operating systems. Software yang digunakan pada penelitian ini adalah YASARA version 20.4.24 (de Groot et al. 1997), Molecular Operating Environment (MOE) MOE 2008.10 (Vilar et al. 2008), dan PyMOL versi 2.3.4 (Schrödinger, LLC, USA, http://www.pymol.org/)

\section{Evaluasi aktivitas biologis dan preparasi ligan}

Senyawa bioaktif yang dipilih dalam docking ini adalah apiin, epicatechin, dan hesperetin. Struktur 2D (2 Dimensi) dan 3D (3 Dimensi) dari apiin, epicatechin, dan hesperetin diperoleh dari PubChem database (https://pubchem.ncbi.nlm.nih.gov/), yang disajikan dalam Tabel 1. Langkah pertama yang dilakukan untuk mengetahui apakah senyawa yang dipilih memiliki spektrum aktivitas biologis adalah analisis PASS (prediction of activity spectra for substances) online (Lagunin et al. 2000). Software ini memprediksi hampir 900 jenis aktivitas berdasarkan struktur suatu senyawa. Masingmasing struktur kemudian diubah menjadi bentuk file SMILES menggunakan software ChemDraw Professional 16.0 dan dianalisis aktivitas biologisnya menggunakan software PASS online (http://www.way2drug.com/passonline/). Untuk persiapan docking, maka masing-masing struktur selanjutnya dipreparasi menggunakan software MOE 2008.10. Persiapan meliputi optimasi geometri ligand dan pembuangan molekul air $\left(\mathrm{H}_{2} \mathrm{O}\right)$. Molekul ligan selanjutnya disimpan dalam format $*$ sdf.

\section{Persiapan struktur protein}

Struktur protein ACE2 diperoleh dari PDB (Protein Data Bank) pada website https://www.rcsb.org/, dengan PDB ID 1R4L (Tabel 2.) yang berasal dari organisme $H$.

Tabel 1. Prediksi PASS senyawa bioaktif

\begin{tabular}{lccc}
\hline Senyawa Bioaktif & $\mathrm{Pa}$ & $\mathrm{Pi}$ & Prediksi Aktivitas Biologis \\
\hline Apiin (PubChem CID: & 0,423 & 0,012 & Antiviral (Hepatitis B) \\
46882564) & 0,430 & 0,030 & CDP-diacylglycerol-serine O-phosphatidyltransferase inhibitor \\
\hline \multirow{2}{*}{ Epicatechin (PubChem } & 0,692 & 0,006 & Antiviral (Influenza) \\
CID 72276) & 0,520 & 0,044 & Antiviral (Rhinovirus) \\
& 0,465 & 0,015 & Antiviral (Herpes) \\
& 0,673 & 0,007 & Antiviral (Influenza) \\
Hesperetin (PubChem CID & 0,564 & 0,010 & Antiviral (Rhinovirus) \\
72281 ) & 0,455 & 0,004 & Antiviral (Hepatitis B) \\
& 0,328 & 0,004 & Inhibitor pemasukan virus ke dalam sel \\
\hline
\end{tabular}

Keterangan: Pa menunjukkan probalititas aktivitas senyawa, Pi mewakili probabilitas senyawa tidak aktif 
Tabel 2. Data PDB makromolekul protein yang digunakan

\begin{tabular}{lc}
\hline \multicolumn{2}{c}{ Spesifikasi } \\
\hline PDB ID & 1R4L \\
Organisme asal & $H$. sapiens \\
Metode analisis struktur & X-ray crystallography \\
Resolusi & $3.00 \AA$ \\
\hline
\end{tabular}

sapiens (Towler et al. 2004). Molekul ACE2 disiapkan dengan menggunakan software YASARA versi 20.4.24. Persiapan yang dilakukan adalah pemisahan gugus $\mathrm{H}_{2} \mathrm{O}$, pemisahan ligan alami ((S,S)-2-\{1-carboxy-2[3-(3,5-Dichloro-Benzyl)-3H-imidazol-4-YL]ethylamino\}-4-methyl-pentanoic acid, Nacetyl-D-glucosamine, ion zinc, dan klorida). Struktur protein dan ligan yang telah dipisahkan selanjutnya disimpan dalam satu folder dengan format $* \mathrm{pdb}$.

\section{Proses molecular docking}

Molecular docking (penambatan molekul) dilakukan menggunakan software MOE 2008.10. Proses pertama dari molecular docking adalah optimasi geometri struktur ligan yang akan diuji untuk menghasilkan energi molekul terendah. Senyawa ligan diperbaiki dengan penambahan atom hidrogen dan muatan parsial gasteiger charges (Sliwoski et al. 2013). Masing-masing senyawa ligan selanjutnya disimpan dalam format $* \mathrm{mdb}$. Penentuan sisi aktif dari reseptor ACE2 selanjutnya dilakukan untuk mengetahui lokasi dan menghitung kemungkinan interaksi sisi aktif dengan ligan senyawa bioaktif dari koordinat atom (Rahman et al. 2019). 1R4L yang diunduh dari PDB adalah dalam bentuk berikatan dengan ligan dan molekul air, sehingga pada tahap persiapan reseptor kedua molekul tersebut dihilangkan. Molekul air pada analisis ini dihilangkan karena pada umumnya tidak terlibat pada pengikatan protein dan ligan, selain itu agar perhitungan docking lebih mudah karena molekul air dapat menyebabkan distorsi pada pencarian sisi aktif (Parikh dan Kellogg 2014).

Reseptor ACE2 dan ligan yang telah dipersiapkan selanjutnya disimulasikan dengan menu compute-simulation-dock pada software MOE 2008.10. Hasil docking disimpan dalam format *mdb. Metode penempatan (triangle matcher) diulang dengan pembacaan energi tiap posisi dan parameter lain yang disesuaikan dengan MOE 2008.10. Hasil yang ditampilkan adalah yang terbaik dari 100 pengulangan.

\section{Analisis docking}

Analisis docking dilakukan menggunakan beberapa parameter dari interaksi ligan-reseptor, yaitu energi ikatan dan konstansta inhibisi (S) terendah, ikatan hydrogen. Ikatan yang terjadi terutama pada sisi aktif yaitu pada asam amino yang sesuai akan dijadikan prediksi sementara serta kemampuan senyawa steroid dan flavonoid yang tertambat pada molekul protein sasaran yang terbesar akan dijadikan sebagai dasar penentuan senyawa dengan aktivitas terbaik (Mukund et al. 2019). Hasil docking kemudian disuperposisikan dengan data asli (PDB ID 1R4L) dan divisualisasikan dengan program PyMOL versi 2.3.4.

\section{HASIL DAN PEMBAHASAN}

Interaksi berperan penting dalam perancangan obat berbasis struktural. Dalam penelitian ini, senyawa bioaktif dipilih berasal dari data sekunder Lin et al. (2019) yang melakukan analisis M. oleifera menggunakan ultra-performance liquid chromatography quadrupole time-of-flight mass spectrometry (UPLC-QTOF-MS). Analisis PASS (Tabel 1) memprediksi apiiin memiliki aktivitas antivirus Hepatitis B dengan nilai $\mathrm{Pa}$ (probablitias untuk aktif) 0,423 . Epicatehin memiliki nilai $\mathrm{Pa} 0,692$ sebagai antivirus influenza. Sedangkan hesperetin memiliki prediksi dengan nilai $\mathrm{Pa}$ 0,673 untuk antiviral influenza.

Tabel 3 menyajikan hasil docking ligan senyawa apiin, epicatechin, dan hesperetin terhadap struktur protein kristal ACE2. Pada analisis ini, molekul target protein ACE2 (PDB 1R4L) dipilih karena merupakan hasil dari analisis X-ray kristalografi. Sebagaimana telah diketahui, $\mathrm{X}$-ray kristalografi merupakan teknik visualisasi struktur molekul pada resolusi atom dan menunjukkan struktur mendekati yang ada di dalam sel (Aitipamula dan Vangala 2017). 1R4L yang dipilih ini berasal dari spesies $H$. sapiens agar hasil docking yang dilakukan mendekati kondisi yang sebenarnya. 
Tabel 3. Hasil docking ligan senyawa terhadap struktur protein kristal ACE2

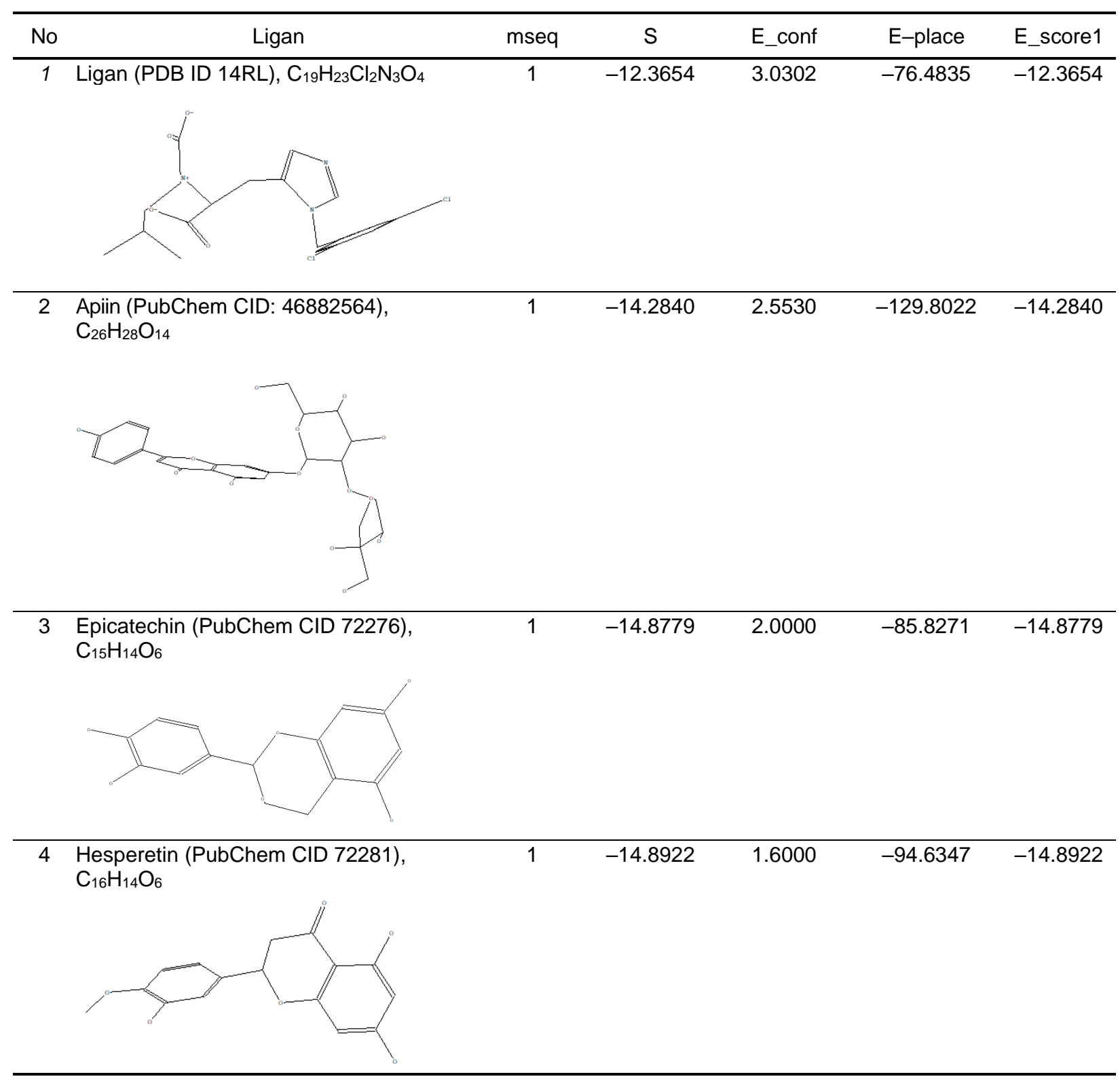

Energi ikatan dan konstansta inhibisi (S) hasil docking 1R4L menunjukkan potensi sebagai senyawa penghambat interaksi ACE2 dan SARS-CoV-2. Berdasarkan analisis docking, hesperetin memiliki afinitas tertinggi dalam berikatan dengan residu asam amino ACE2, yaitu glutamate sebesar 2,03 $\AA$.

Interaksi antara asam amino glutamat (Glu406) senyawa M. oleifera dan ACE2 diamati pada ikatan hidrogen yang terbentuk, dimana ikatan ini terjadi jika jarak antara hidrogen dengan atom elektronegatif berada pada rentang 2,5-3,5 $\AA$ (Berg et al. 2002). Tabel 4 menunjukkan interaksi ligan senyawa dengan residu asam amino pada sisi aktif ACE2. Residu asam amino Glu406 menjadi sisi aktif terbaik dari ligan hesperetin.
Gambar 1 hingga 4 menyajikan ligan yang berinteraksi dengan sisi aktif dari ACE2. Masing-masing ligan memiliki residu asam amino yang menjadi target dalam proses docking. Interaksi ditampilkan secara 2D, dimana ligan ditampilkan dengan model ball dan stick, sedangkan kontak residu digambarkan dengan model line (garis).

Gambar 5 menyajikan superposisi dari PDB ID14RL, ligan apiin, epicatechin, dan hesperetin yang berikatan dengan sisi aktif dari ACE2. Superposisi ini dibuat sebagai konfirmasi bahwa ligan yang di-docking dapat berperan sebagai inhibitor kompetitif potensial yang dapat mengikat sisi aktif ACE2. 
Ikatan antara residu asam amino pada sisi aktif dan ligan diharapkan mampu menghilangkan fungsi enzimatik dari ACE2, sehingga menurunkan interaksi SARS-CoV2. Analisis in silico yang dilakukan Laksmiani et al. (2020) menunjukkan bahwa senyawa apigenin, luteolin, dan quercetin dari $M$. oleifera memiliki aktivitas mengikat ACE2 dan berpotensi dalam menghambat infeksi SARSCoV-2. Oo et al. (2016) melaporkan bahwa hesperetin dan apiin memiliki aktivitas penghambatan infeksi Virus Chikungunya.

Tabel 4. Ikatan hidrogen antara ligan dan residu asam amino, serta panjang interaksinya

\begin{tabular}{lccc}
\hline Senyawa & Nomor lkatan Hidrogen & Panjang* & Residu Asam Amino \\
\hline Ligan 1R4L & 1 & 2,74 & Arg273 \\
& 2 & 2,93 & Arg273 \\
& 3 & 2,66 & His345 \\
& 4 & 2,70 & His505 \\
\hline Apiin & 1 & 2,68 & His378 \\
& 2 & 3,23 & His378 \\
& 3 & 2,79 & Glu402 \\
& 4 & 3,41 & Glu402 \\
& 5 & 2,68 & His378 \\
& 6 & 3,23 & His378 \\
& 7 & 3,25 & Arg514 \\
\hline Epicatechin & 1 & 3,43 & Pro346 \\
& 2 & 3,30 & Thr371 \\
\hline Hesperetin & 1 & 2,03 & Glu406 \\
& 2 & 3,25 & Arg273 \\
& 3 & 2,76 & Thr371 \\
& 4 & 3,06 & Arg518 \\
\hline
\end{tabular}

* Ikatan hidrogen terbentuk jika jarak antara hidrogen dengan atom elektronegatif berada pada rentang $2.5-3.5 \AA$
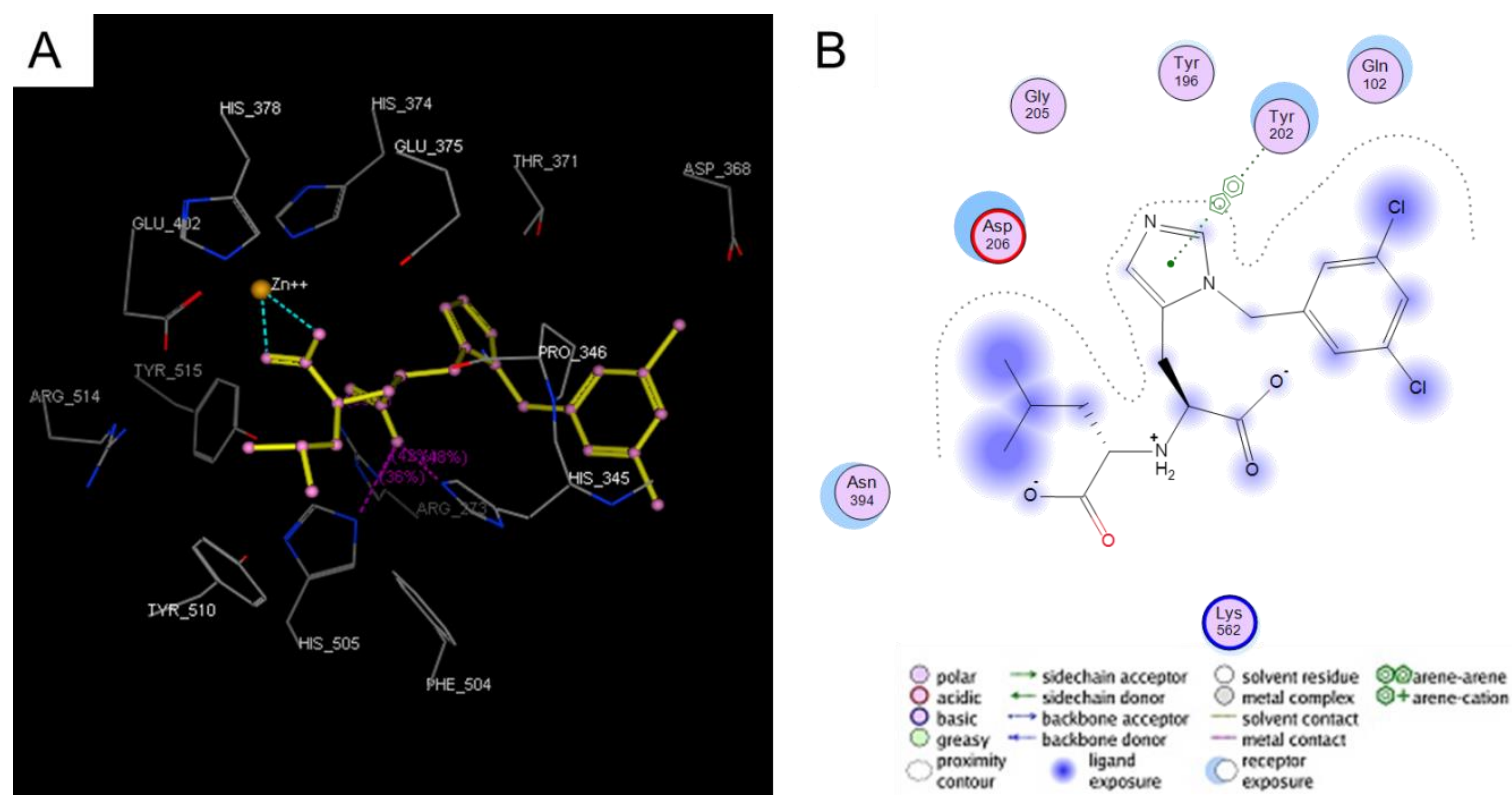

Gambar 1. Konformasi makromolekul ACE2 dan ligan 5-[3-[4-(3,5-dichloro-2-methoxyphenyl)piperidin-1-yl]-3oxopropyl]-5-methylimidazolidine-2,4-dione. (A) Animasi 2D ligan (warna kuning) dalam sisi aktif 1R4L; (B) Interaksi ligan dengan residu asam amino dari ACE2. Komplek dihasilkan dari interaksi ligan MOE 2008.10 
Analisis fluorometric yang dilakukan oleh Wang et al. (2009) menyebutkan bahwa apiin memiliki aktivitas penghambatan infeksi virus Influenza melalui spesifitasnya dalam berikatan dengan neuraminidase (NA).

Epicatechin dilaporkan memiliki potensi dalam menghambat replikasi virus Hepatitis C (Lin et al. 2013). Uji in vivo yang dilakukan Ferreira et al. (2018) menyebutkan epicatehin dari Salacia crassifolia mampu menghambat replikasi virus Mayaro penyebab Mayaro Fever. Analisis docking yang dilakukan ini memberikan gambaran potensi lebih lanjut, hesperetin, epicatechin dan apiin sebagai antivirus dan besar kemungkinan memiliki kemampuan yang sama dalam melawan dan mencegah infeksi COVID-19.

Pandemi virus corona pernah menjangkit manusia dan hewan. Virus ini menyebabkan infeksi pernapasan, pencernaan, hati dan sistem saraf pusat (Su et al. 2020b). Munculnya varian virus corona, SARS-CoV-2, menjadikan ancaman besar bagi kesehatan manusia di seluruh dunia. Upaya penemuan senyawa untuk mengatasi infeksi SARS-CoV-2 dilakukan dengan langkah identifikasi dan karakterisasi kandidat senyawa baru. Tanaman obat telah lama dikenal akan kandungan senyawa bioaktifnya yang penting sebagai kandidat agen antivirus yang kuat (Atanasov et al. 2015, Ogbole et al. 2018). Salah satu
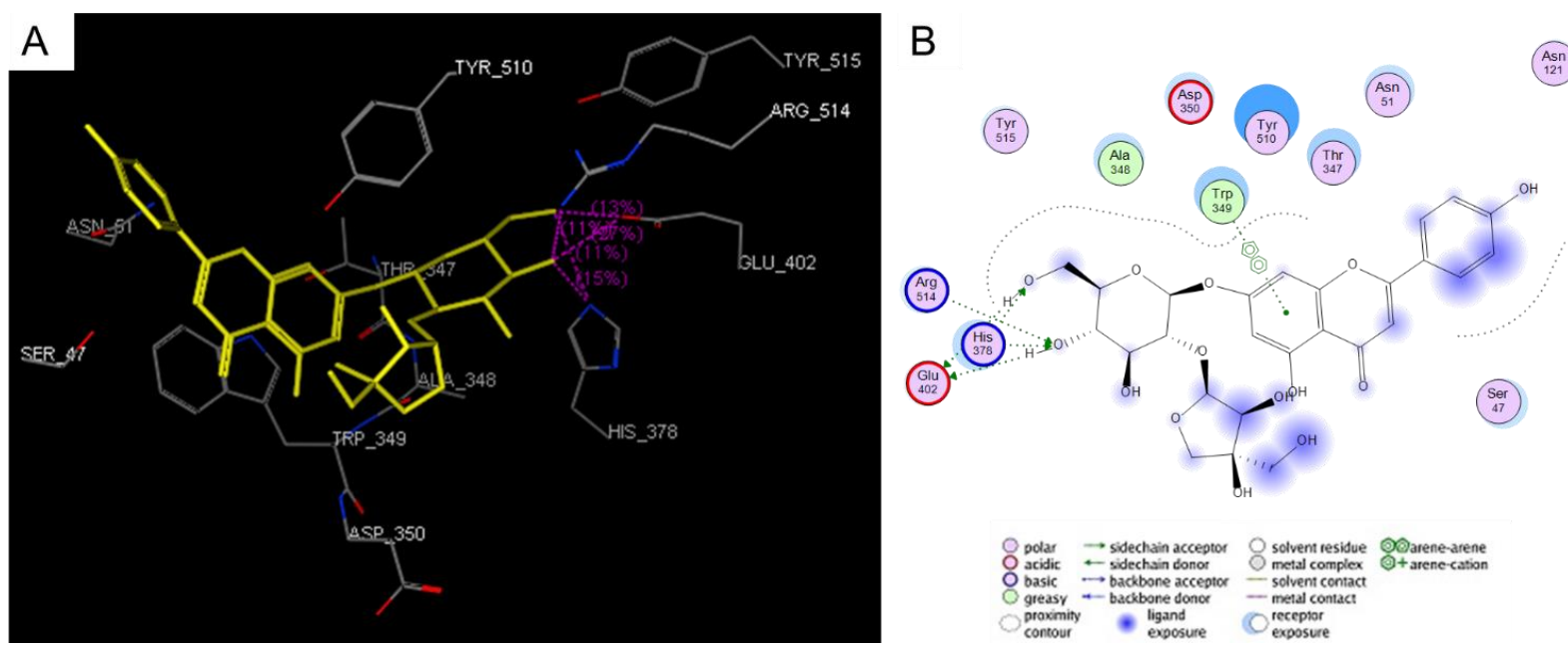

Gambar 2. Konformasi-docking ACE2 dan ligan senyawa apiin. (A) Animasi 2D ligan (warna kuning) dalam sisi aktif 1R4L; (B) Interaksi ligan dengan residu asam amino dari ACE2. Komplek dihasilkan dari interaksi ligan MOE 2008.10
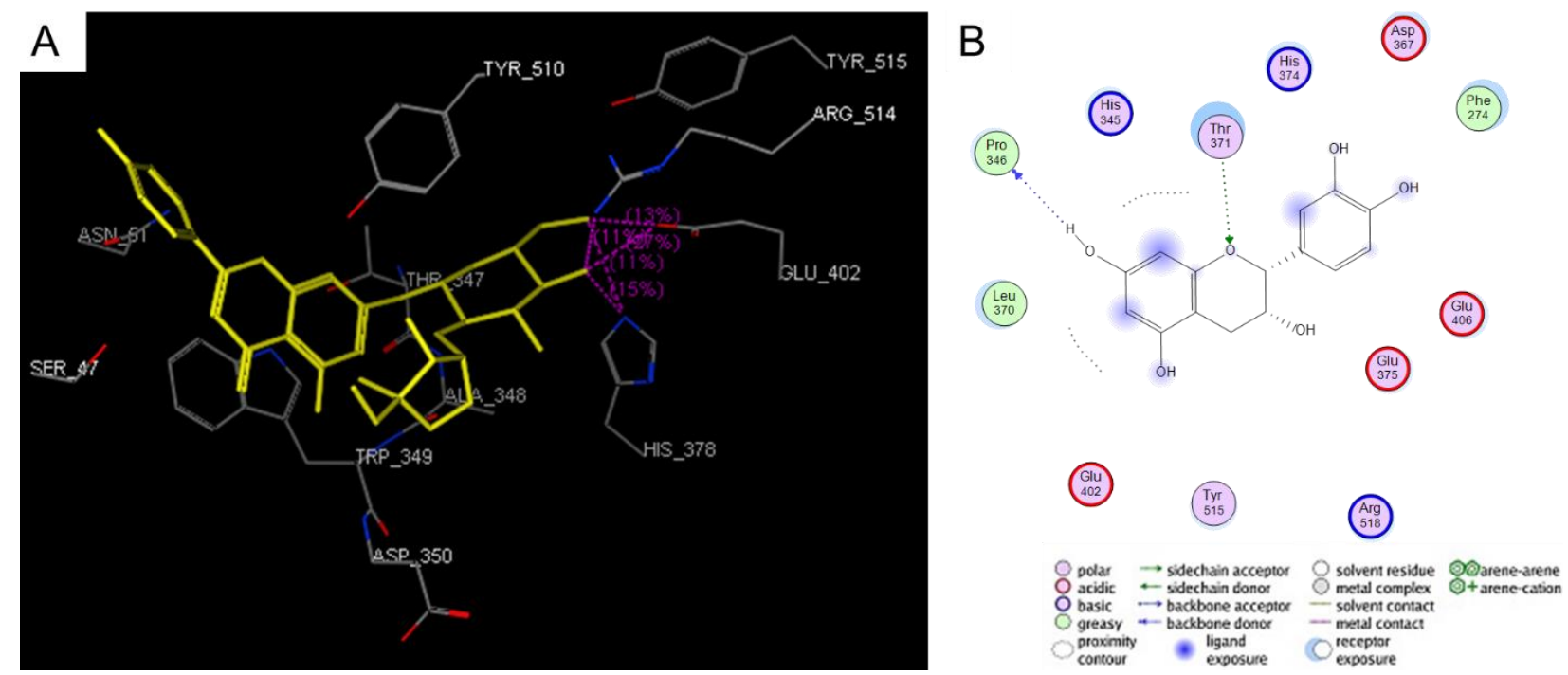

Gambar 3. Konformasi-docking ACE2 dan ligan senyawa epicatechin. (A) Animasi 2D ligan (warna kuning) dalam sisi aktif 1R4L; (B) Interaksi ligan dengan residu asam amino dari ACE2. Komplek dihasilkan dari interaksi ligan MOE 2008.10 

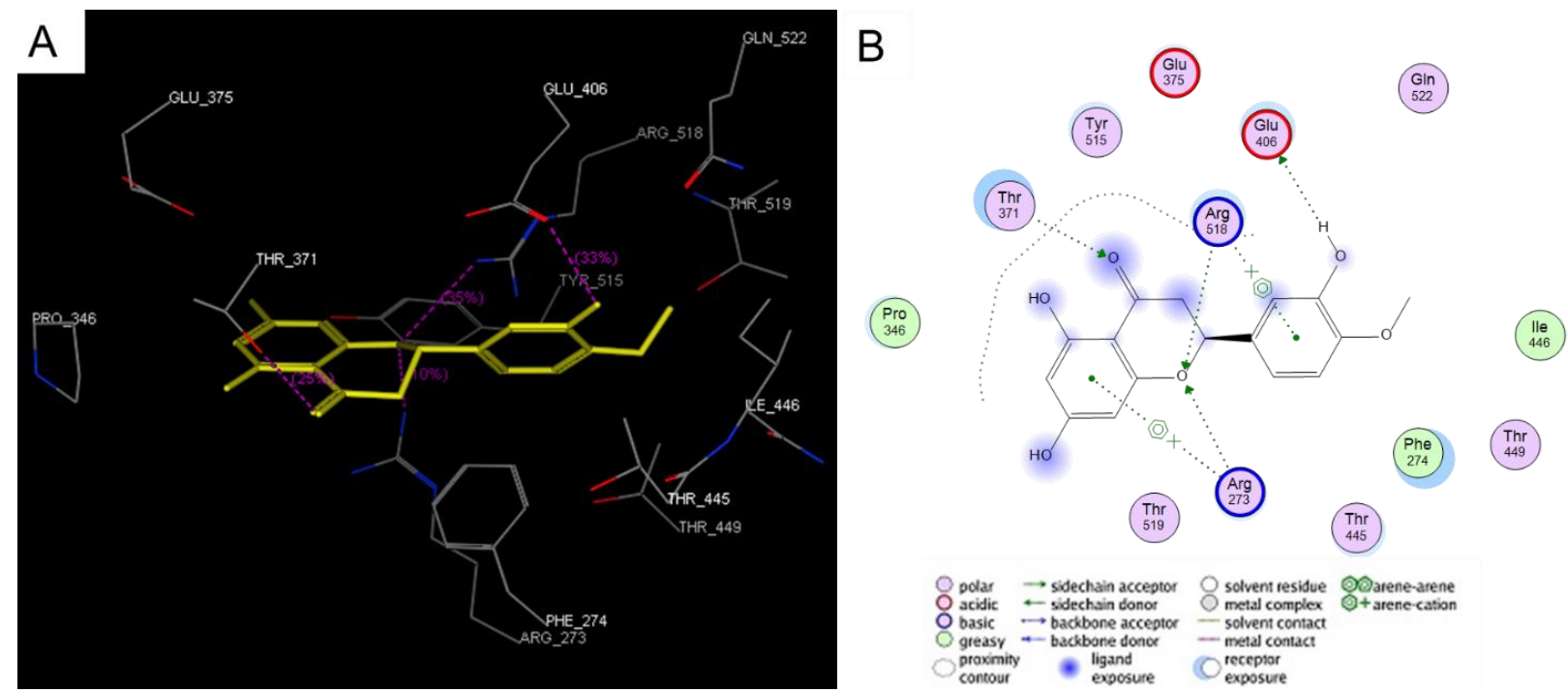

Gambar 4. Konformasi-docking ACE2 dan ligan senyawa hesperetin. (A) Animasi 2D ligan (warna kuning) dalam sisi aktif 1R4L; (B) Interaksi ligan dengan residu asam amino dari ACE2. Komplek dihasilkan dari interaksi ligan MOE 2008.10

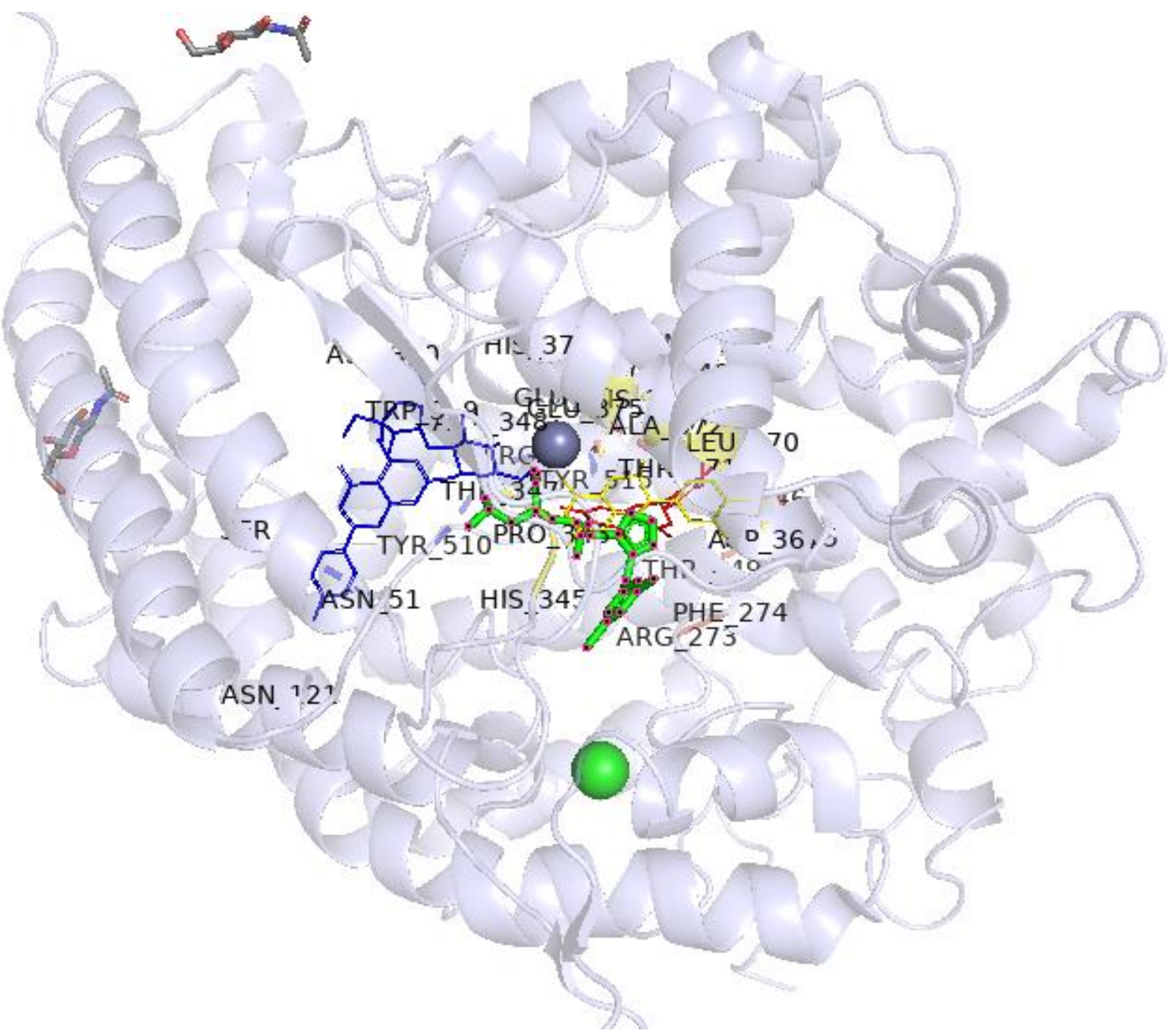

Gambar 5. Representasi simulasi docking dari komplek ACE2 dengan ligan. Ketiga ligan ditampilkan dalam mode stik berada di dalam sisi aktif dari 1R4L (warna silver), yaitu 5-[3-[4-(3,5-dichloro-2-methoxyphenyl)piperidin-1yl]-3-oxopropyl]-5-methylimidazolidine-2,4-dione (warna hijau), apiin (warna biru), epicatechin (warna kuning), dan hesperetin (warna merah). Komplek dihasilkan dari PyMOL versi 2.3.4 
tanaman yang dikenal luas akan kandungan senyawanya yang beragam adalah $M$. oleifera (Feustel et al. 2017, Vergara-Jimenez et al. 2017). Analisis docking merupakan langkah awal dalam proses identifikasi senyawa yang mampu menghambat ikatan reseptor protein spike SARS-CoV-2 pada ACE2 sel $H$. sapiens. Apiin, epicatechin, dan hesperetin termasuk ke dalam kelompok flavonoid, dimana pada umumnya, flavonoid memiliki kemampuan dalam berikatan dengan reseptor seluler (Zakaryan et al. 2017), sehingga kemampuan ini diharapkan dapat menghambat infeksi SARS-CoV-2. Ketiga ligan ini diseleksi dengan mencari struktur energi yang rendah. Struktur energi yang rendah menunjukkan kestabilan konformasi struktur kimia yang akan memberikan hasil mendekati akurat ketika proses docking (Huang et al. 2012).

\section{KESIMPULAN}

Pandemi COVID-19 yang menyebar dengan cepat telah menjadi tantangan bagi seluruh institusi pendidikan untuk berkontribusi dalam melawan infeksi SARS-CoV-2. Analisis moleculer docking kompleks ACE2 dengan beberapa senyawa dari $M$. oleifera dilakukan untuk mengidentifikasi ligan yang berpotensi menghambat interaksi SARS-CoV-2 dengan sel manusia. Hasil analisis molecular docking menunjukkan bahwa kandungan flavonoid pada $M$. oleifera seperti apiin, epicatechin dan hesperetin memiliki afinitas pengikatan yang baik terhadap sisi aktif ACE2. Hasil skor MOE menunjukkan afinitas flavonoid dapat peringkat sebagai berikut oleh afinitas hesperetin > epicatechin > apiin $>\mathrm{C}_{19} \mathrm{H}_{23} \mathrm{Cl}_{2} \mathrm{~N}_{3} \mathrm{O}_{4}$. Hasil analisis ini diharapkan mendukung dan membantu peneliti yang akan melakukan eksplorasi potensi senyawa bioaktif di laboratorium basah, terutama untuk senyawa apiin, epicatechin dan hesperetin dalam terapi melawan COVID-19. Namun, studi lebih lanjut harus dilakukan untuk memvalidasi senyawa ini menggunakan model in vitro dan in vivo, sehingga memberikan informasi lebih lanjut bagi kandidat antiviral SARS-CoV-2.

\section{UCAPAN TERIMA KASIH}

Penulis menyampaikan terima kasih kepada Universitas Nahdlatul Ulama Surabaya yang telah membiayai penelitian ini
(Nomor: 361.94/UNUSA/Adm-LPPM/IV/2020) dan semua pihak yang telah membantu terselesaikannya karya tulis ilmiah ini.

\section{DAFTAR PUSTAKA}

Aitipamula S, Vangala VR (2017) X-ray crystallography and its role in understanding the physicochemical properties of pharmaceutical cocrystals. J Indian Inst Sci 97: 227-243. doi: 10.1007/s41745-017-0026-4

Atanasov AG, Waltenberger B, PferschyWenzig EM, Linder T, Wawrosch C, Uhrin P, Temml V, Wang L, Schwaiger S, Heiss EH, Rolliger JM, Schuster D, Breuss JM, Bochkov V, Mihovilovic MD, Kopp B, Bauer R, Dirsch VM, Stuppner H (2015) Discovery and resupply of pharmacologically active plant-derived natural products: A review. Biotechnol Adv 33: 1582-1614. doi: 10.1016/j.biotechadv.2015.08.001

Bahadur S, Long W, Shuaib M (2020) Human coronaviruses with emphasis on the COVID-19 outbreak. Virusdisease 31: 1-5. doi: 10.1007/s13337-020-00594-y

Berg JM, Tymoczko JL, Stryer L (2002) Biochemistry. $5^{\text {th }}$ edition. WH Freeman, New York

Blaising J, Levy PL, Polyak SJ, Stanifer M, Boulant S, Pecheur El (2013) Arbidol inhibits viral entry by interfering with clathrin-dependent trafficking. Antiviral Res 100: 215-219. doi: 10.1016/j.antiviral.2013.08.008

Cantini F, Niccoli L, Matarrese D, Nicastri E, Stobbione P, Goletti D (2020) Baricitinib therapy in COVID-19: A pilot study on safety and clinical impact. J Infect 81: 318-356. doi: 10.1016/j.iinf.2020.04.017

de Groot BL, van Aalten DMF, Scheek RM, Amadei A, Vriend G, Berendsen HJC (1997) Prediction of protein conformational freedom from distance constraints. Proteins 29: 240-251. doi: $10.1002 /(\mathrm{SICl}) 1097$

0134(199710)29:2<240::AID-

PROT11>3.0.CO;2-O

Ferreira PG, Ferraz AC, Figueiredo JE Lima CF, Rodrigues VG, Taranto AG, Ferreira JMS, Brandão GC, VieiraFilho SA, Duarte LP, de Brito Magalhães CL, de Magalhães JC (2018) Detection of the antiviral activity 
of epicatechin isolated from Salacia crassifolia (Celastraceae) against Mayaro virus based on protein $\mathrm{C}$ homology modelling and virtual screening. Arch Virol 163: 1567-1576. doi:10.1007/s00705-018-3774-1

Feustel S, Ayón-Pérez F, SandovalRodriguez A, Rodriguez-Echevarria R, Contreras-Salinas $\mathrm{H}$, ArmendarizBorunda J, Sanchez-Orozco LV (2017) Protective effects of Moringa oleifera on HBV genotypes $\mathrm{C}$ and $\mathrm{H}$ transiently transfected Huh7 cells. J Immunol Res 2017: $6063850 . \quad$ doi $: 10.1155 / 2017 / 6063850$

Heller L, Mota CR, Greco DB (2020) COVID19 faecal-oral transmission: Are we asking the right questions? Sci Total Environ 729: 138919 . doi: 10.1016/j.scitotenv.2020.138919

Huang W, Ravikumar KM, Parisien M, Yang $S$ (2016) Theoretical modeling of multiprotein complexes by iSPOT: Integration of small-angle X-ray scattering, hydroxyl radical footprinting, and computational docking. J Struct Biol 196: 340-349. doi: 10.1016/j/jsb.2016.08.001

Imamsari M, Koentjoro MP, Nurhayati AP Isdiantoni, Prasetyo EN (2018) In vivo preliminary examination of Moringa oleifera leaves extract as antiaging candidate in Swiss webster male mice (Mus musculus). Int J Pharm Sci Res 9: 3638-3646. doi: 10.13040/ IJPSR.09758232.9(9).3638-46

Jia H (2016) Pulmonary angiotensin-converting enzyme 2 (ACE2) and inflammatory lung disease. Shock 46: 239-248. doi: 10.1097/SHK.0000000000000633

Kementerian Kesehatan (2020) Pedoman Pencegahan dan Pengendalian Coronavirus Disease (COVID-19). Revisi ke-3. Direktorat Jenderal Pencegahan dan Pengendalian Penyakit, Kementerian Kesehatan RI, Jakarta

Khan $\mathrm{H}$, Jaiswal V, Kulshreshtha S, Khan A (2019) Potential angiotensin converting enzyme inhibitors from Moringa oleifera. Recent Pat Biotechnol 13: 239-248. doi: 10.2174/1872208313666190211114229

Lagunin A, Stepanchikova A, Filimonov D, Poroikov V (2000) PASS: prediction of activity spectra for biologically active substances. Bioinformatics 16: 747-748. doi: 10.1093/bioinformatics/16.8.747

Laksmiani NPL, Larasanty LPF, Santika AGGJ, Prayoga PAA, Dewi AAIK, Dewi NPA (2020) Active compounds activity from medicinal plants against SARSCoV-2 using in silico assay. Biomed Pharmacol J 13: 873-881. doi: 10.13005/bpj/1953

Lin YT, Wu YH, Tseng CK, Lin CK, Chen WC, Hsu YC, Lee JC (2013) Green tea phenolic epicatechins inhibit hepatitis $\mathrm{C}$ virus replication via cycloxygenase-2 and attenuate virus-induced inflammation. PLoS One 8: e54466. doi: /10.1371/journal.pone.0054466

Lin $\mathrm{H}$, Zhu H, Tan J, Wang H, Wang Z, Li P, Zhao C, Liu J (2019) Comparative analysis of chemical constituents of Moringa oleifera leaves from China and India by ultra-performance liquid chromatography coupled with quadrupole-time-of-flight mass spectrometry. Molecules 24: 942. doi: 10.3390/molecules24050942

Lisi L, Lacal PM, Barbaccia ML, Graziani G (2020) Approaching coronavirus disease 2019: Mechanisms of action of repurposed drugs with potential activity against SARS-CoV-2. Biochem Pharmacol 180: 114169. doi: 10.1016/j.bcp.2020.114169

Mourad JJ, Levy BI (2020) Interaction between RAAS inhibitors and ACE2 in the context of COVID-19. Nat Rev Cardiol 17: 313. doi: 10.1038/s41569020-0368-x

Mukund V, Behera SK, Alam A, Nagaraju GP (2019) Molecular docking analysis of nuclear factor-kB and genistein interaction on the context of breast cancer. Bioinformation 15: 11-17. doi: 10.6026/97320630015011

Ogbole OO, Akinleye TE, Segun PA, Faleye TC, Adeniji AJ (2018) In vitro antiviral activity of twenty-seven medicinal plant extracts from Southwest Nigeria against three serotypes of echoviruses. Virol $\mathrm{J}$ 15: 110 . doi: 10.1186/s12985-0181022-7

Oo A, Hassandarvish P, Chin SP, Lee VS, Abu Bakar S, Zandi K (2016) In silico study on anti-Chikungunya virus activity of hesperetin. Peer J 4: e2602. doi: 10.7717/peerj.2602

Parikh HI, Kellogg GE (2014) Intuitive, but not 
simple: Including explicit water molecules in protein-protein docking simulations improves model quality. Proteins 82: 916-932. doi: 10.1002/prot.24466

Rahman N, Muhammad I, Gul-E-Nayab HK, Aschner M, Filosa R, Daglia M (2019) Molecular docking of isolated alkaloids for possible a-glucosidase inhibition. Biomolecules 9: 544 . doi: 10.3390/biom9100544

Riastiwi I, Damayanto IPGP, Ridwan R, Handayani T, Leksonowati A (2018) Moringa oleifera distribution in Java and Lesser Sunda islands attributed with annual rainfall. Biosaintifika 10: 613-621. doi: 10.15294/biosaintifika.v10i3.16115

Saha P, Banerjee AK, Tripathi PP, Srivastava AK, Ray U (2020) A virus that has gone viral: Amino acid mutation in $S$ protein of Indian isolate of coronavirus COVID19 might impact receptor binding, and thus, infectivity. Biosci Rep 40: BSR20201312. 10.1042/bsr20201312

Schrezenmeier E, Dorner T (2020) Mechanisms of action of hydroxychloroquine and chloroquine: Implication for rheumatology. Nat Rev Rheumatol 16: 155-156. doi: 10.1038/s41584-020-0372-x

Sharifi N, Souri E, Ziai AS, Amin G, Amanlou $M$ (2013) Discovery of new angiotensin converting enzyme (ACE) inhibitors from medicinal plants to treat hypertension using an in vitro assay. Daru 21: 74. doi: 10.1186/2008-223121-74

Sliwoski G, Kothiwale S, Meiler J, Lowe Jr EW (2013) Computational methods in drug discovery. Pharmacol Rev 66: 334-395. doi: 10.1124/pr.112.007336

Su L, Ma X, Yu H, Zhang Z, Bian P, Han Y, Sun J, Liu Y, Yang C, Geng J, Zhang Z, Gai Z (2020a) The different clinical characteristics of corona virus disease cases between children and their families in China - the character of children with COVID-19. Emerg Microbes Infect 9: 707-713. doi: 10.1080/22221751.2020.1744483

Su J, Shen X, Ni Q, Zhao H, Cai J, Zhu B, Wu W, Lang G, Xu K, Sheng J (2020b) Infection of severe acute respiratory syndrome coronavirus 2 in a patient with AIDS. AIDS 34: 1575-1576. doi: 10.1097/QAD.0000000000002553

Sun J, Chen YT, Fan XD, Wang XY, Han QY, Liu ZW (2020) Advances in the use of chloroquine and hydroxychloroquine for the treatment of COVID-19. Postgrad Med 132: 604-613. doi: 10.1080/00325481.2020.1778982

Towler P, Staker B, Prasad SG, Menon S, Tang J, Parsons $\mathrm{T}$, Ryan D, Fisher $\mathrm{M}$, Williams D, Dales NA, Patane MA, Pantoliano MW (2004) ACE2 X-ray structures reveal a large hinge-bending motion important for inhibitor binding and catalysis. J Biol Chem 279: 1799618007. doi: 10.1074/jbc.M311191200

Vergara-Jimenez $M$, Almatrafi MM, Fernandez ML (2017) Bioactive components in Moringa oleifera leaves protect against chronic disease. Antioxidants (Basel) 6: 91. doi: 10.3390/antiox6040091

Vilar S, Cozza G, Moro S (2008) Medicinal chemistry and the molecular operating environment (MOE): Application of QSAR and molecular docking to drug discovery. Curr Top Med Chem 8: $1555-1572$. doi: $10.2174 / 156802608786786624$

Wang HD, Du GH, Liu A (2009) Evaluation for inhibitory effects of natural flavonoids on neuraminidases. Chinese $\mathrm{J}$ New Drugs 15: 1435-1439

WHO (2020) Report of the WHO-China Joint Mission on Coronavirus Disease 2019 (COVID-19). World Health Organization, Geneva Switzerland

Wiese O, Zemlin AE, Pillay TS (2020) Molecules in pathogenesis: Angiotensin converting enzyme 2 (ACE2). J Clin Pathol 2020: 1-6. doi:10.1136/jclinpath2020-206954

Xia S, Liu M, Wang C, Xu W, Lan Q, Feng S, Qi F, Bao L, Du L, Liu S, Qin C, Sun F, Shi Z, Zhu Y, Jiang S, Lu L (2020) Inhibition of SARS-CoV-2 (previously 2019-nCoV) infection by a highly potent pan-coronavirus fusion inhibitor targeting its spike protein that harbors a high capacity to mediate membrane fusion. Cell Res 30: 343-355. doi: 10.1038/s41422-020-0305-x

Xu J, Zhao S, Teng T, Abdalla AE, Zhu W, Xie L, Wang Y, Guo X (2020) Systmetic comparison of two animal-to-human 
transmitted human coronavirusses: SARS-CoV-2 and SARS-CoV. Viruses 12: 244. doi: 10.3390/v12020244

Zakaryan H, Arabyan E, Oo A, Zandi K (2017) Flavonoids: Promising natural compounds against viral infections.
Arch Virol 162: 2539-2551. doi: 10.1007/s00705-017-3417-y

Zheng YY, Ma YT, Zhang JY, Xie X (2020)

COVID-19 and the cardiovascular system. Nat Rev Cardiol 17: 259-260. doi: 10.1038/ s41569-020-0360-5 